\title{
Perancangan Sistem Absensi Berbasis Web pada Program Studi PTI UNIMUDA Sorong
}

\author{
Rut Chrystin Saragi Napitu, Indri Anugrah Ramadhani, Firman Firman \\ Program Studi Pendidikan Teknologi Informasi \\ Universitas Pendidikan Muhammadiyah Sorong
}

rutchrystinsaraginapitu@gmail.com, indianugrah18@gmail.com, firmantajdiduliman@gmail.com

\begin{abstract}
Abstrak: Penelitian ini bertujuan untuk membuat Perancangan Sistem Absensi Berbasis Web pada Program Studi PTI FKIP UNIMUDA Sorong. Jenis penelitian ini menggunakan pendekatan penelitian dan pengembangan (Research and Development) dan menggunakan model perancangan waterfall. Penelitian dilaksanakan di Program Studi PTI FKIP UNIMUDA Sorong dan waktu penelitian mulai dari bulan Mei 2019 sampai dengan bulan Oktober 2019. Pada penelitian ini menggunakan 5 teknik analisa data yaitu, mengembangkan instrumen, menentukan sampel penelitian, melakukan pengumpulan data, melakukan analisa data, dan interpretasi data. Perhitungan nilai rerata dan nilai presentase sampel menggunakan metode Skala Likert. Produk yang dihasilkan dari penelitian ini adalah Sistem Absensi Berbasis Web
\end{abstract}

Kata kunci : Sistem, Absensi, Web, Perancangan

\section{Pendahuluan}

Peranan komputer di era globalisasi sekarang ini sangat penting dalam pengolahan informasi. Di lingkup perguruan tingggi berdasarkan Pasal 11 Ayat 1 terdapat pernyataan "Pemerintah Dan Pemerintah Daerah Wajib Memberikan Pelayanan Dan Kemudahan, Serta Menjamin Terselenggaranya Pendidikan Yang Bermutu Bagi Setiap Warga Negara Tanpa Diskriminasi". ( Undang-Undang Nomor 20 Tahun 2003 ). Upaya pemerintah dalam melaksankan amanat UndangUndang 1945 dan UU No 20 Tahun 2003 tersebut diatas antara lain dengan memanfaatkan kemajuan Teknologi Infomasi dalam dunia pendidikan. Adapaun studi literature yang relevan dengan penelitian ini adalah:

Hasil penelitian oleh Latif Cahyono dengan judul "Perancangan Sistem Informasi Absensi Siswa Berbasis Web di SMK YPKK 1 Sleman Yogyakarta", jenis penelitian yang digunakan dalam penelitian ini adalah pendekatan penelitian dan pengembangan atau Research and Development $(R \& D)$. Model pengembangan yang digunakan dalam penelitian ini adalah model waterfall. Dari hasil penelitian ini sistem yang dibuat menghasilkan beberapa fungsi, antara lain mengeloah data guru piket, mengelolah data kelas dan data siswa, dan fungsi lainnya yang dapat dilakukan oleh admin. Melihat data guru piket, mengelolah data kelas, dll yang dapat diakses oleh guru piket dan fungsi melihat data siswa rekap absensi siswa yang dapat di akses oleh pengguna tamu. Sedangkan peneliti membuat sistem absensi yang hanya dapat diakses oleh Dosen dan Sekretaris kelas untuk pengisian absensi kehadiran perkuliahan. 
Hasil penelitian yang dilakukan oleh Surbiantoro dan Sardiarinto dengan judul "Perancangan Sistem Absensi Pegawai Berbasis Web", metode yang digunakan dalam penelitian ini yaitu metode model air terjun (waterfall), adapun sistem yang dirancang ini menghasilkan aplikasi absensi berbasis website Kantor Kecamatan Purwodadi yang memberikan kemudahan bagi pegawai dalam mengelola dan mengakses informasi baik dari segi penggunaannya maupun proses pembuatan laporan. Dengan menggunakan aplikasi absensi berbasis web pegawai dapat meminimalisir kehilangan dan kesalahan pencatatan data baik dalam proses absensi itu sendiri maupun pembuatan laporan absensi. Data absensi dapat diolah secara terstruktur yang dapat memberikan kemudahan kepada pegawai dalam proses pencarian data absensi. Penelitian oleh Surbiantoro dan Sardiarinto mempermudah proses absensi bagi pegawai sedangkan peneliti merancang sistem absensi web untuk mempermudah pengisian absensi oleh dosen dan sekretaris kelas.

Program Studi Pendidikan Teknologi Informasi merupakan salah satu Prodi pada Fakultas Keguruan dan Ilmu Pendidikan di Kampus UNIMUDA Sorong. Program Studi PTI dan juga Program Studi lain yang berada di Kampus UNIMUDA Sorong menggunakan buku absensi sebagai laporan kehadiran setiap mahasiswa dalam mengikuti proses perkuliahan. Buku laporan absensi didapatkan dari Sekretaris Program Studi yang seterusnya buku tersebut di berikan kepada Sekretaris Kelas untuk mengisi kehadiran dari teman-teman sekelasnya. Setiap 1 (satu) kelas mendapatkan 1 buku laporan absensi. Pada buku laporan absensi tersebut berisi : NIM, Nama Lengkap Mahasiswa, Nama Mata Kuliah, Nama Dosen Pengampuh, Waktu Perkuliahan, dan Kolom Kehadiran sebanyak 16 kolom (tatap muka selama 1 semester). Program Studi PTI melaksanakan proses perkuliahan sebanyak 2-3 kali tatap muka dalam sehari, setiap proses perkuliahan berlangsung mahasiswa wajib mengisi absen dengan memberikan paraf. Selain buku laporan kehadiran, mahasiwa Program Studi PTI juga memilki KMK (Kartu Mata Kuliah) sebagai bukti setiap kehadiran mahasiswa mengikuti mata kuliah dikelas yang di paraf oleh dosen, sedangkan dosen menggunakan daftar hadir pada Microsoft Office Excel untuk mendata kehadiran mahasiswa yang mengikuti proses perkuliahan dosen tersebut.

Pengisian laporan kehadiran merupakan sebuah kegiatan rutin yang harus dilakukan oleh Sekretaris Kelas. Kegiatan yang dilakukan setiap ada tatap muka perkuliahan ini dapat menimbulkan kerusakan pada buku laporan kehadiran tersebut. Sedangkan buku tersebut sangat penting di gunakan untuk mengkalkulasikan kehadiran Mahasiswa pada akhir semester. Selain dapat terjadi kerusakan karena sering di gunakan, tidak menutup kemungkinan buku laporan kehadiran tersebut dapat hilang.

\section{Metode Penelitian}

Jenis penelitian ini menggunakan pendekatan penelitian dan pengembangan (research and development). Menurut Borg \& Gall (1983:772) yang dikutip oleh Prof. Dr. Emzir, M. Pd, (2012 :270), Riset dan pengembangan bidang pendidikan $(R \& D)$ adalah suatu proses yang digunakan untuk mengembangkan dan mengesahkan produk bidang pendidikan Adapun model pengembangan yang digunakan dalam penelitian adalah model waterfall. Menurut 
Pressman waterfall adalah model klasik yang bersifat sistematis, berurutan dalam membangun software

Teknik analisis data yang digunakan adalah Teknik analisis data dalam penelitian ini menggunakan statistik deskriptif. Statistik deskriptif adalah statistik yang digunakan untuk menganalisis data dengan cara mendeskripsikan atau menggambarkan data yang telah terkumpul adanya tanpa bermaksud membuat kesimpulan yang berlaku untuk umum atau generalisasi kemudian statistik deskriptif yang digunakan dalam penelitian ini adalah penyajian data dengan tabel, perhitungan rata-rata, standar deviasi dan persentase. Teknik dan instrument pengumpulan data dilakukan dalam 4 metode yaitu (1) Wawancara, (2) Observasi, (3) Studi Pustaka, dan (4) Angket

\section{Hasil dan Pembahasan}

Produk yang dihasilkan dari penelitian perancangan ini adalah sistem informasi absensi berbasis web. Desain produk dibuat berdasarkan storyboard dan database yang telah dibuat berdasarkan kebutuahan sistem. Berikut adalah tampilan halaman yang dapat diakses oleh user. Halaman log in user akan diminta untuk memasukkan username dan password. Jika log in berhasil, maka akan masu ke halaman utama. Desain tampilan dapat dilihat pada gambar 1 .

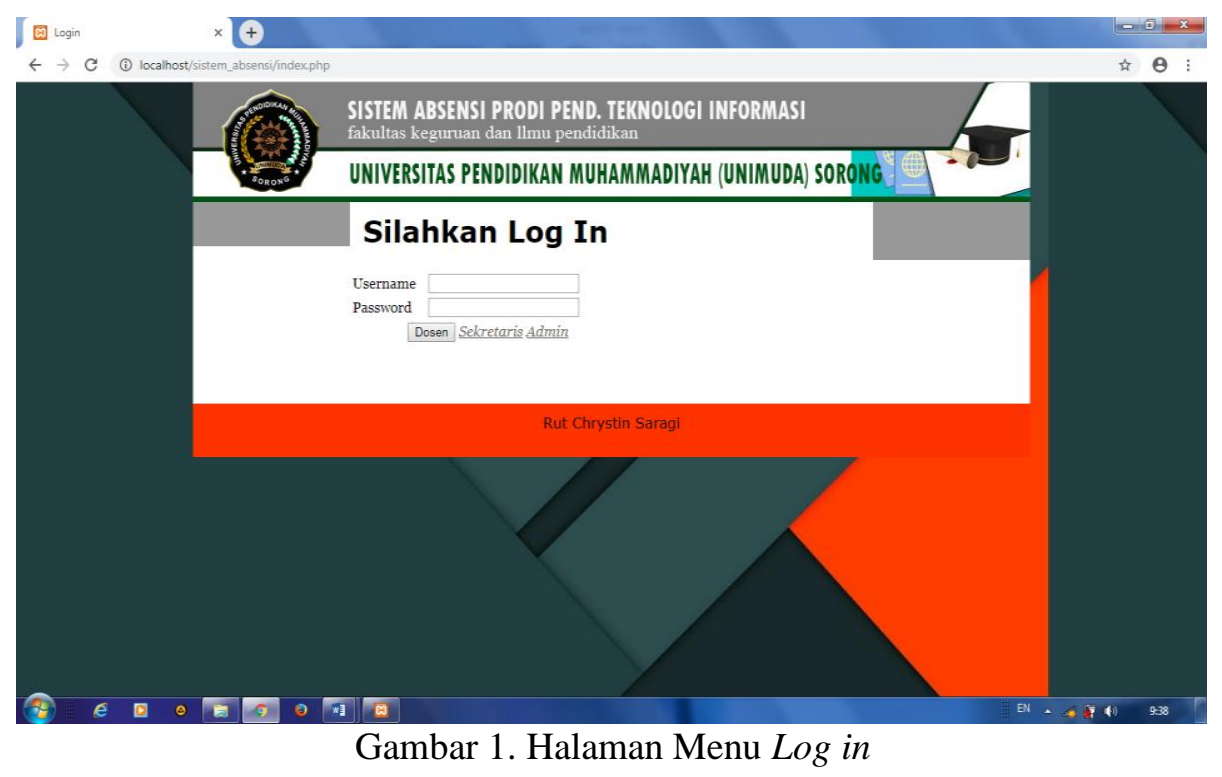

Halaman beranda dosen akan menampilkan data mata kuliah yang diampuh oleh dosen yang bersangkutan dan terdapat pilihan kelas yang mengampuh mata kuliah tersebut. Menu kelas ini akan masuk pada data kehadiran masing-masing kelas. Selain terdapat menu mata kuliah yang diampuh, user dosen juga dapat mengakses menu Data Mahasiswa, Data Dosen, dan Data Mata Kuliah pada baagian sudut kiri tampilan web. 


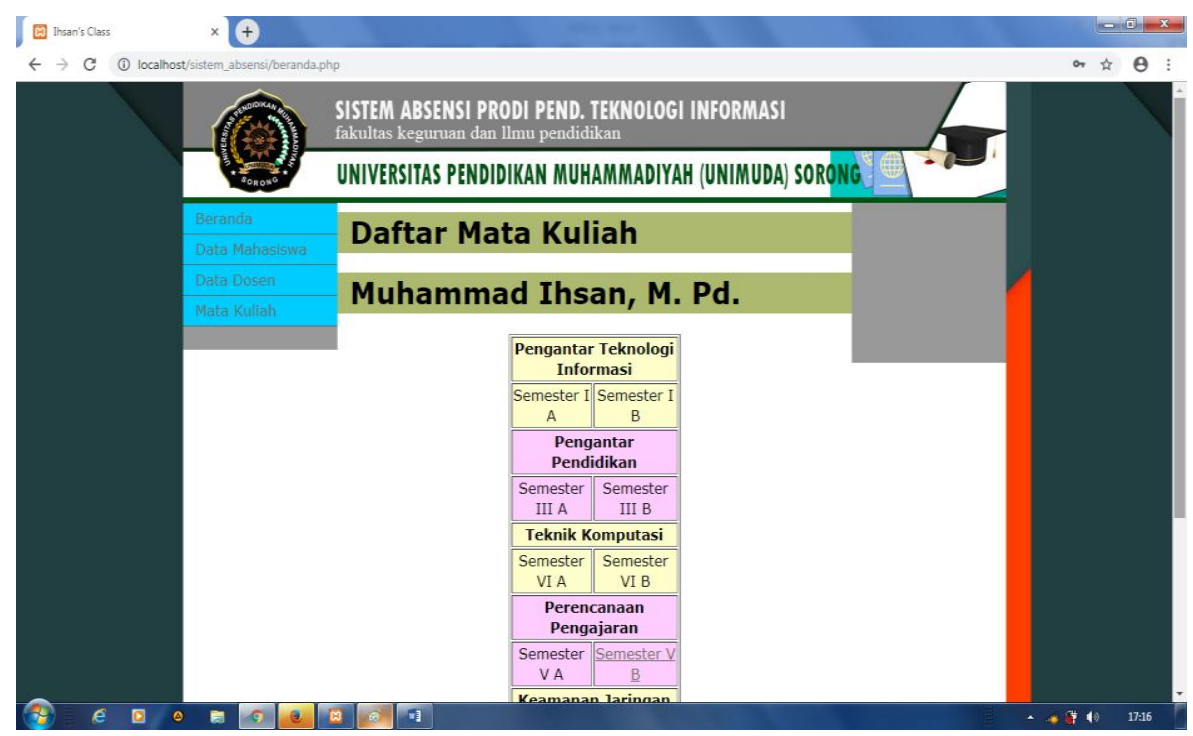

Gambar 2. Halaman Beranda

Pada halaman ini akan menampilkan NIM, Nama, Hari, Waktu, Tempat proses perkuliahan berlangsung dan daftar kehadiran dari Pertemuan 1 sampai dengan Pertemuan 16. Pada daftar kehadiran, dosen dapat mengisi keterangan kehadiran dari mahasiswa dengan cara klik menu Edit, dan pilih kehadiran misalnya hadir, sakit, izin, alpa atau pindah jam. Selain itu, dosen juga dapat menambahkan data mahasiswa baru, merubah data mahasiswa yang sudah ada, menghapus data mahasiswa dan dapat menyimpan atau mencetak data kehadiran mahasiswa.. Dapat kita lihat pada Gambar 3.

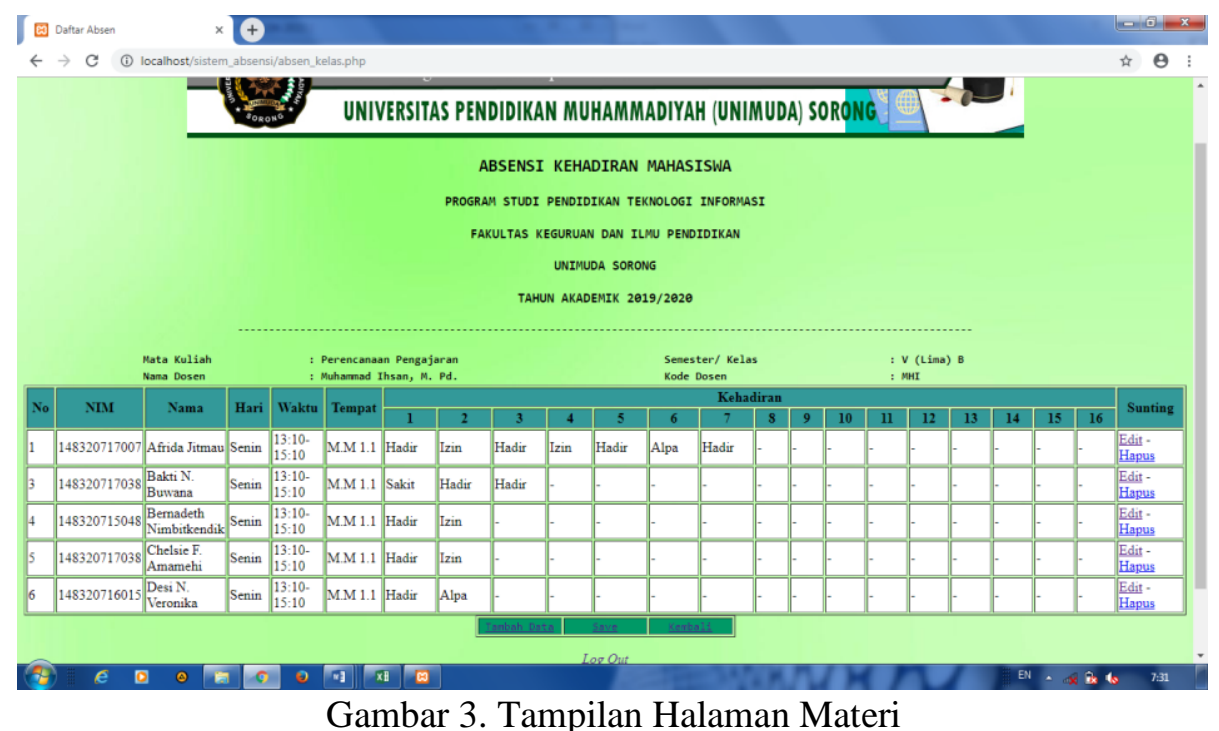


Pada halaman data mahasiswa kita dapat melihat identitas diri dari masingmasing mahasiswa. Contoh pada gambar dibawah ini adalah halaman data mahasiswa Prodi PTI Semester V Kelas B. User sektretaris kelas dapat merubah dan menambahkan data dari teman sekelasnya. Dapat di lihat pada Gambar 4.

\begin{tabular}{|c|c|c|c|c|c|c|c|c|c|}
\hline (Ihson's Class & $\times$ 回 & att Dosen & $\times$ & & $\times$ & & & & $a+x$ \\
\hline$\leftarrow \rightarrow C$ C (1) local & Ihost/sistem_absen: & isemester5.php & & & & & & & $\theta:$ \\
\hline & & & & DATA I & HASISWA & & & & \\
\hline & & PROGRAM 5 & TUDI PEI & DIKAN & NOLOGI INFC & ASI SEMEST & & & \\
\hline & & & FAKULTA & KEGURUA & AN ILMU PE & DIKAN & & & \\
\hline & & & & UNIML & SORONG & & & & \\
\hline & & & & IHUN AKA & IIK 2019/2020 & & & & \\
\hline NIM & Nama & No Hp & Alamat & Agama & Tanggal Lahir & Tempat Lahir & Jenis Kelamin & Sunting & \\
\hline 148320717007 & Afrida Jitmau & - & - & $\begin{array}{c}\text { Kristen } \\
\text { Protestan }\end{array}$ & - & Sorong & Perempuan & Edit-Hapus & \\
\hline 148320717014 & $\begin{array}{c}\text { Arimas D. } \\
\text { Tiranti }\end{array}$ & - & - & Islam & - & - & Perempuan & Edit-Hapus & \\
\hline 148320717039 & $\begin{array}{l}\text { Bakti N. } \\
\text { Buwana }\end{array}$ & - & - & Islam & - & - & Laki-Laki & Edit-Hapus & \\
\hline 148320717037 & \begin{tabular}{|c|} 
Bernadeth \\
Nimbitkendik \\
\end{tabular} & - & - & $\begin{array}{c}\text { Kristen } \\
\text { Protestan }\end{array}$ & - & - & Laki-Laki & Edit-Hapus & \\
\hline 148320717038 & $\begin{array}{l}\text { Chelsie F. } \\
\text { Amamehi }\end{array}$ & - & - & $\begin{array}{l}\text { Kristen } \\
\text { Protestan }\end{array}$ & - & - & Perempuan & Edit-Hapus & \\
\hline 148320716015 & $\begin{array}{c}\text { Desi Nataliaa } \\
\text { Veronika }\end{array}$ & - & - & $\begin{array}{c}\text { Kristen } \\
\text { Protestan }\end{array}$ & - & - & Perempuan & Edit-Hapus & \\
\hline 148320717028 & \begin{tabular}{|c|} 
Maulina Intant \\
Wulandari
\end{tabular} & - & - & Islam & - & - & Perempuan & Edit-Hapus & \\
\hline 148320717043 & $\begin{array}{c}\text { Muhammad } \\
\text { Lutfi Dzulfikar }\end{array}$ & o82248393047 & Sorong & Islam & 1998-08-12 & Wamena & Laki-Laki & Edit-Hapus & \\
\hline
\end{tabular}

Gambar 4. Halaman Data Mahasiswa

Hasil ujicoba pemakaian meliputi: (1) aspek pemrograman, (2) aspek isi, (3) aspek tampilan, serta (4) aspek efisiensi. Dari hasil uji coba pemakaian, data yang diperoleh diharapkan dapat menggambarkan penilaian pengguna terhadap media pembelajaran. Hasil penilaian dari uji coba pemakaian disajikan dalam Tebel 1

Tabel 1 Tabel Uji Coba

\begin{tabular}{|c|c|c|c|c|}
\hline Skala Besar & Indikator & Nilai & Rata - Rata & Kategori \\
\hline \multirow{5}{*}{$\begin{array}{l}\text { Uji Produk } \\
\text { Sistem } \\
\text { Absensi }\end{array}$} & $\begin{array}{l}\text { Aspek } \\
\text { Pemrograman }\end{array}$ & 4,46 & $89,25 \%$ & $\begin{array}{l}\text { Sangat } \\
\text { Baik }\end{array}$ \\
\hline & Aspek Isi & 4,57 & $91,5 \%$ & $\begin{array}{c}\text { Sangat } \\
\text { Baik }\end{array}$ \\
\hline & Aspek Tampilan & 4,23 & $84,77 \%$ & $\begin{array}{c}\text { Sangat } \\
\text { Baik }\end{array}$ \\
\hline & Aspek Efisiensi & 4,4 & $88 \%$ & $\begin{array}{c}\text { Sangat } \\
\text { Baik }\end{array}$ \\
\hline & Jumlah & 17,66 & $87,31 \%$ & $\begin{array}{c}\text { Sangat } \\
\text { Baik }\end{array}$ \\
\hline
\end{tabular}

Berdasarkan data dari tabel hasil uji coba oleh kelompok kecil yang terdiri dari 20 sampel dan 4 indikator yaitu, (1) Aspek pemograman memiliki skor rerata sebesar 4,46 dan nilai presentase berada pada kategori sangat baik, yaitu sebesar 89,25\%. (2) Aspek isi memiliki skor rerata sebesar 4,57 dan nilai presentase berada pada kategori sangat baik, yaitu sebesar 91,5\%. (3) Aspek tampilan memiliki skor rerata sebesar 4,23 dan nilai presentase berada pada kategori sangat baik, yaitu sebesar 84,77\%. (4) Aspek efisiensi memiliki skor rerata sebesar 4,4 dan nilai presentase berada pada kategori sangat 
baik, yaitu sebesar $88 \%$ dan di dapatkan jumlah dari keseluruhan indikator dengan ratarata 87,31\% dengan kategori Sangat Baik.

\section{Kesimpulan}

Penelitian ini menghasilkan produk berupa Sistem Absensi Berbasis Web Pada Prodi PTI FKIP UNIMUDA Sorong. Tahapan yang dilakukan untuk menghasilkan sebuah sistem absensi berbasis web antara lain, pengumpulan data, perencanaan, pengembangan bentuk awal produk, uji lapangan dan revisi produk, dan yang terakhir adalah implementasi Hasil penilaian dari uji coba produk mendapatkan nilai rata - rata sebesar 87,31 dalam kategori sangat baik. Sehingga dapat disimpulkan bahwa sistem absensi berbasis web ini layak digunakan.

\section{Daftar Pustaka}

Arief Ramadhan, S. K. (2007). Macromedia Dreamweaver 8. Jakarta: PT Elex Media Komputindo.

Aryantio, A., \& Irianto, T. (2013). Pembuatan Sistem Informasi Perpustakaan

Smp Muhammadiyah 7 Surakarta. Jurnal Speed - Sentra Penelitian Engineering Dan Edukasi, $\quad$ 5(1), 15-20. https://doi.org/10.3112/speed.v4i4.1099

Astuti, P. (2018). Penggunaan Metode Black Box Testing (Boundary Value Analysis) Pada Sistem Akademik (SMA/SMK), 11(2), 186-195. https://doi.org/10.30998/faktorexacta.v11i2.2510

Dwiyoga, A. (2005). Membangun Mail Server Andal dengan Fedora dan Qmail. Jakarta: PT Elex Media Komputindo.

EMS, T. (2015). Kamus Komputer Lengkap. Jakarta: PT Elex Media Komputindo.

Retrieved from elizabet@elexmedia.co.id

Enterprise, J. (2016). Pengenalan HTML dan CSS. Jakarta: PT Elex Media Komputindo.

Fatta, H. Al. (2007). Analisis \& Perancangan Sistem Informasi. (Agnes Heni Triyuliana, Ed.) (1st ed.). Yogyakarta: Penerbit ANDI.

Huda, M., \& Komputer, B. (2005). Membuat Aplikasi Database Dengan Java, MySQL, dan NetBeans. Jakarta: Elex Media Komputindo.

Kusrini, M. K. (2007). Strategi Perancangan dan Pengelolaan Basis Data. (A. H. Triyuliana, Ed.). Yogyakarta: C.V ANDI OFFSET.

Mulyanto, A. R. (2008). Rekayasa Perangkat Lunak Jilid 1. Jakarta: Direktorat Pembinaan Sekolah Menengah Kejuruan, Direktorat Jenderal Manajemen Pendidikan Dasar dan Menengah, Departemen Pendidikan Nasional.

Prasetyo, I. (2008). Teknik analisis data dalam research and development.

Setiawan, R. (2007). Sistem Operasi. (Soetam Rizky Wicaksono, Ed.) (1st ed.). Malang: CV. Seribu Bintang. 
S.Pressman, R. (2010). Software Engineering A Practitioner's Approach 7th Edition. McGraw-Hill Higher Education.

Sugiyono, 2012. Metode Penelitian Kuantitatif Kualitatif dan $R \& D$. Bandung:Alfabeta.

Tata Sutabri. (2012). Konsep Sistem Informasi. (I. Nastiti, Ed.) (1st ed.). Yogyakarta: Penerbit ANDI.

Yuhezfizar. (2008). 10 Jam Menguasai Internet:Teknologi dan Aplikasinya. Jakarta: PT Elex Media Komputindo. 